\title{
Kirkbyites Johnson, an ostracod genus indicative of pelagic palaeo-environments
}

\author{
GERHARD BECKER \\ Geological Palaeontological Institute \\ Johnann Wolfgang Geothe University \\ Senckenberg-Anlage 32-34 \\ 6000 Frankfurt/Main, Germany
}

\author{
HORST BLUMENSTENGEL \\ Geological Survey \\ Sachsen-Anhalt \\ Köthener Straße 34 \\ 0-4060 Halle/Saale, Germany
}

\begin{abstract}
A third Kirkbyites species, K. hercynicus sp. nov., is described from the early Upper Devonian (early Famennian) of the Harz Mountains (Central Europe) to join the other two known species of the genus Kirkbyites upsoni Johnson, the Upper Carboniferous type species from Nebraska (U.S.A.), and the late Upper Devonian Kullmannissites? solus Becker from N Spain (W Europe). Its biotype indicative carapace features, characteristic of marine low-energy palaeo-environments, place Kirkbyites Johnson, 1936 (Ostracoda, Palaeocopida, Kirkbyacea, Amphissitidae) into Becker's "Thuringian" ecotype. J. Micropalaeontol., 11 (2): 229-231, December 1992.
\end{abstract}

\section{INTRODUCTION}

In 1981 Becker described a peculiar amphissitid species, Kullmannissites solus from the pelagic Upper Devonian (late Famennian) of northern Spain. Because of its "intermediate" characters, this taxon was believed to be a "chimera", resembling Kullmannissites Becker, 1981 (lobation) as well as Sinessites Becker, 1981 (anterodorsally located carinal flange) (see Becker 1981, pp. 29-33).

Studying the original material of Kirkbyites upsoni Johnson, 1936 from the Upper Pennsylvanian Eudora Shale of Nebraska (U.S.A.), however, it became evident to the present author that Kullmannissites? solus belongs to Johnson's (at that time rather unknown) genus Kirkbyites which is considered to be a valid member of the Family Amphissitidae Knight, 1928 (Kirkbyacea, Palaeocopina).

Recently, a third species, Kirkbyites hercynicus sp. nov., was detected in the early Upper Devonian (early Famennian) of the Harz Mountains showing clearly the diagnostic characters of Kirkbyites Johnson: comparatively narrow subcentral lobe + posterodorsal spine + anterodorsally located carinal flange + narrow carapace width (see Becker, 1991, p. 29).

This new record consolidates the genus, which until now has been of a doubtful status.

\section{SYSTEMATICS}

Order Palaeocopida Henningsmoen, 1953

Suborder Palaeocopiana Henningsmoen, 1953

Superfamily Kirkbyacea Ulrich \& Bassler, 1908

Family Amphissitidae Knight, 1928 Kirkbyites hercynicus sp. nov.

(Pl. 1, figs 1-5)

Derivation of name. After the Harz Mountains.

Holotype. Adult LV, Pl. 1, Fig. 5, SMF Xe 16911.

Type locality. Left (southern) valley slope of Bode river at Rübeland village, about $8 \mathrm{~km}$ SW Blankenburg, central Elbingeröde Reef complex, Harz Mountains, Germany; lat. $51^{\circ} 45^{\prime} \mathrm{N}$, long. $10^{\circ} 50^{\prime} \mathrm{W}$. Micritic cephalopod limestones, Upper crepida conodont-zone, Famennian, Upper Devonian. (For further information, see Weyer 1991, p.25). Fragment of bedrock with rich and well preserved, silicified ostracod fauna of the "Thuringian" ecotype dominated by tricorninid and bythocypridid species.

Paratypes.Juvenile LV, P1. 1, Fig. 1, SMF Xe 16907; juvenile LV, Pl. 1, Fig.2, SMF Xe 16908; juvenile LV, Pl. 1, Fig. 3, SMF Xe 16909; juvenile LV, Pl. 1, Fig. 4, SMF XE 16910; all specimens are topotype material.

Diagnosis. Medium-sized Kirkbyites species with small, but distinct subcentral lobe and subdued posterior shoulder, superposed by short lateral ridge terminating in an upwardly directed spine. Two carinae developed; outer carina curving around anterior cardinal angle above dorsum; inner carina subparallel to outer carina, antero-and posterodorsally hardly obscured. Lateral surface delicately reticulate.

Remarks. Kirkbyites hercynicus sp. nov. resembles $K$. solus (Becker). In the new species, however, the spine is directed straight upwards and seems (especially in the larval forms) less strong than in the Spanish species. The type species, $K$. upsoni Johnson, is characterized by its very prominent posterodorsal node. Moreover, in the new taxon the inner carina is hardly obscured below the cardinal angles and the outer carina anterodorsally slightly bent outward (see Pl. 1, Figs $3 b, 4 b, 5 b, 5 f)$.

\section{PALAEOECOLOGY}

The Upper Devonian (Famennian) species, K. solus (Becker, 1981) and $K$. hercynicus sp. nov., are from pelagic facies; the same may be true for the Upper Carboniferous (Upper Pennsylvanian) type species, K. upsoni Johnson, 1936. The Spanish species comes from a basinal deposit (cf. Becker \& Bless 1990, Text figs 7,12 ), the new species from a lime mud buildup "accumulated in open-marine quiet water" (Weller 1989, p.335), always low-energy habitats. All Kirkbyites species are thin shelled and show dorsally located spines, features 
considered to be biotope indicative of marine low-energy palaeo-environments, quiet independent of absolute water depth (see Becker \& Bless 1990, p.422). Such forms charactererize Becker's "Thuringian" ecotype (eco-assemblage). The species under consideration were probably nectobenthic filter feeders (see Becker \& Adamczak 1990, p.96).

\section{ACKNOWLEDGEMENTS}

The material collected in the Harz Mountains was kindly made available to the present authors by Dr Dieter Weyer (Magdeburg).

\section{Manuscript received September 1992}

Manuscript accepted September 1992

\section{REFERENCES}

Becker, G. 1981. Ostracoden aus cephalopoden-führendem Oberdevon im Kantabrischen Gebirge (N-Spanien). 1. Hollinacea, Primitiopsacea, Kirkbyacea, Healdiacea und Bairdiocypridacea. Palaeontographica, Stuttgart, A173, 1-63, 7 Text figs, 2 tabs, Pls 1-11.

Becker, G. 1991. Kirkbyites Johnson, a valid genus from the Upper Palaeozoic. J. micropalaeont., London, 10(1), 29-31, Pl. 1.

Becker, G. \& Adamczak, F.J. 1990. Aurikirkbya wordensis (Hamilton): ein vermutlich filtrierender palaeocopider Ostracode. Paläont. Z., Stuttgart, 64(1/2), 91-102, 5 Text figs.

Becker, G.\& Bless, M.J.M. 1990. Biotope indicative features in Palaeozoic ostracods: a global phenomenon. In: Whatley, R. \& Maybury, C. (Eds), Ostracoda and global events. Br. micropalaeont. Soc. Publ. Ser., Chapman \& Hall, London, 421-436, 12 Text figs.

Johnson, W.R. 1936. The Ostracoda of the Missouri series in Nebraska. Pap. Nebraska Geol. Surv., Lincoln/Nebraska, 11, 1-52, Pls 1-5.

Weller, H. 1989. Das Rübeländer Mud Mound im Riffkomplex von Elbingeröde (Harz) und seine sedimentolkogischen Eigenschaften. Hercynia N.F., Leipzig, 26, 321-337, 12 Text figs.

Weyer, D. 1991. Rugosa (Anthozoa) aus dem Unter-Famenne von Rübeland (Harz). Abh. Ber. Naturkd. Vorgesch., Magdeburg, 15, 2543, 8 Text figs, Pls 1-2.

Explanation of Plate 1

Figs 1-5. Kirkbyites hercynicus sp. nov.; Rübeland, Harz Mountains; Upper crepida conodont-zone, Famennian, Upper Devonian. Magnification about $\times 75$, fig. 5 e ca. x175. Phot. Camscan, Frankfurt/Main.

Fig. 1. Juvenile LV, paratype, SMF Xe 16907; external view (length $-0.81 \mathrm{~mm}$ ).

Fig. 2. Juvenile LV, paratype, SMF Xe 16908; external lateral view (length $-0.59 \mathrm{~mm}$ ).

Fig. 3. Juvenile LV, paratype, SMF Xe 16909; a) external lateral view, b) dorsal oblique view (length $-0.78 \mathrm{~mm}$ ).

Fig. 4. Juvenile LV, paratype, SMF Xe 16910; a) external lateral view, b) dorsal oblique view (length $=0.84 \mathrm{~mm}$.).

Fig. 5. Adult LV, holotype SMF Xe 16911; a) external lateral view, b) dorsal view of slightly tilted anterior part of valve showing outwardly bend carinal flange (length $=1.09 \mathrm{~mm}$ ). 


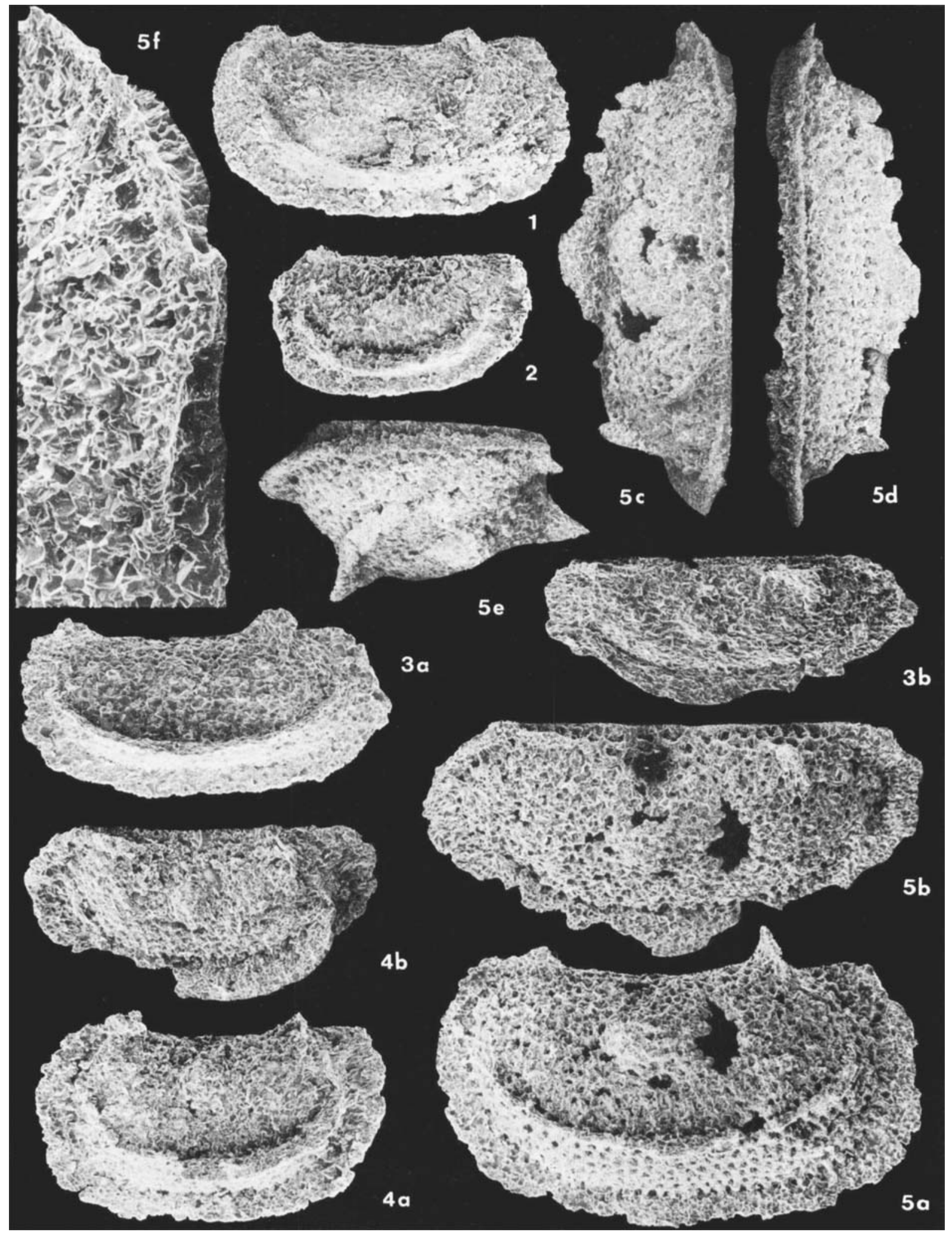

